OnLine Journal of Biological Sciences 11 (1): 1-6, 2011

ISSN 1608-4217

(C) 2011 Science Publications

\title{
Using Randomly Amplified Polymorphic DNA-Polymerase Chain Reaction of Barbodes spp. in Thailand
}

\author{
${ }^{1}$ Keeravit Petjul, ${ }^{2}$ Aphidech Sangdee and ${ }^{2}$ Bungorn Thaewnon-ngiw \\ ${ }^{1}$ Department of Biotechnology, Faculty of Agro-Industrial Technology, \\ Rajamangala University of Technology Isan, Kalasin Campus, Kalasin, Thailand \\ ${ }^{2}$ Department of Biology, Faculty of Science, Mahasarakam University, Mahasarakam, Thailand
}

\begin{abstract}
Problem statement: The genetic diversity of Barbodes species in Thailand is presently unavailable. The objectives of this study were to study external morphology and genetic diversity using Randomly Amplified Polymorphic DNA-Polymerase Chain Reaction (RAPD-PCR) of three Barbodes species; Barbodes altus, B. gonionotus and Barbodes sp. Approach: Two of twelve screened decanucleotide primers (OPA07 and UBC122), were selected for the genetic analysis of Barbodes genera. Results: Thirty-five reproducible and polymorphic fragments (250-2150 bp in length) were generated across the investigated species. The percentages of polymorphic band were 7.69, 3.85 and $6.25 \%$ for B. altus, B. gonionotus and Barbodes sp., respectively. The UPGMA indicated a similarity coefficient between B. gonionotus and Barbodes sp. up to $90 \%$. The candidate species-specific marker of UBC122 primer was found in only Barbodes sp. Conclusion: This approach indicates that Barbodes sp. may be a variant species of B. gonionotus.
\end{abstract}

Key words: Genetic diversity, Barbodes, DNA analysis, RAPD-PCR

\section{INTRODUCTION}

The diverse family Cyprinidae, the most speciesrich family of all vertebrates, has been paid only limited attention in population genetics studies. In the few studies available, the primary focus has been on a few species that have shared the status of being either commercially important or popular game fish; exemplified by studies on common carp, Cyprinus carpio L. (Desvignes et al., 2001; Fuchs et al., 2000; Zhou et al., 2003), gold fish, Carassius auratus L. (Zhou et al., 2001), European chub, Leuciscus cephalus L. (Larno et al., 2005) and the genetic model species zebrafish, Danio rerio Hamiltion (Shimoda et al., 1999). The family Cyprinidae with about 2,000 species seems to have originated in Southeast Asia but now is also distributed in fresh water lakes, rivers and streams of Europe, Asia, Africa and North America. About half the known species are native to Asia. Many important ornamental and aquarium fish belong to this family, ranging from barbs, danios and rasboras to goldfish such as Carassius auratus and carp, Cyprinus carpio which have ornamental varieties. Because of the great ecological and economical importance of Cyprinidae as cultured food fish, many species have been distributed almost globally from their original range in Eurasia. In
Thailand, the genus Barbodes has been cultivated because of the occurrence of high-backed and deepbodied individuals with few scales and rapid growth (Bond, 1996). Moreover, it is highly efficient in food utilization. It is also well accepted as food. Rainboth (1996) identified the genus Barbodes using such external characteristics as serrated dorsal-fin spines, 8 branched pelvic-fin rays, and skin of the lower lip separated from the lower jaw by a shallow groove, analfin base length that is $90 \%$ of head length and no tubercles on the snout. He identified 3 Barbodes species in the Klong River: Barbodes gonionotus, B. altus and B. schwanenfeldii. These species are also distributed in rivers in every region of Thailand and as a result genetic markers are unavailable for the great majority of cyprinids. Since 2004, a fisherman from Surin province in northeastern Thailand, has been culturing B. gonionotus for several generations and has found that the body color of new generations changed in some individuals. Also offspring tend to increase in numbers when inbreeding occurs. This new fish strain looks like B. gonionotus but its body color is golden.

Classification of Barbodes has been based principally on external morphological characters. However, characteristics are apparently influenced by a variety of habitats and environmental conditions. Thus, two sympatric species may be morphologically similar

Corresponding Author: Keeravit Petjul, Department of Biotechnology, Faculty of Agro-Industrial Technology,

Rajamangala University of Technology Isan, Kalasin Campus, Kalasin, 46000, Thailand

Tel: 66-872327465 Fax: 66-43812972 
but misidentified as a single species. On the other hand, allopatric populations inhabiting different habitats may show ecomorphological variation and have questionable species status. The basic information on numbers of species and/or population in a particular area is important for conservation programs (Carvalho and Hauser, 1994). In an earlier study, Holmen et al. (2005) established a platform for optimization of microsatellite markers for six different cyprinids based on cross-species amplification of markers that initially were developed for $D$. rerio and central stoneroller (Campostoma anomalum Rafinesque). Knowledge of genetic variation of Barbodes species in Thailand is, therefore, important for creating appropriate management schemes. However, information about genetic diversity of Barbodes species in Thailand is presently unavailable. Therefore, the objectives of this study were to study external morphology and genetic diversity using Randomly Amplified Polymorphic DNA-Polymerase Chain Reaction (RAPD-PCR) of three Barbodes species.

RAPD reactions are PCR reactions, but they amplify segments of DNA which are essentially unknown to the scientist (random). Often, PCR is used to amplify a known sequence of DNA. Thus, the scientist chooses the sequence he or she wants to amplify, then designs and makes primers which will anneal to sequences flanking the sequence of interest. Thus, PCR leads to the amplification of a particular segment of DNA. However, in RAPD analysis, the target sequence (s) (to be amplified) is unknown. The scientist will design a primer with an arbitrary sequence. In other words, the scientist simply makes up a 10 base pair sequence (or may have a computer randomly generate a 10 bp sequence), then synthesizes the primer. The scientist then carries out a PCR reaction and runs an agarose gel to see if any DNA segments were amplified in the presence of the arbitrary primer. We chose RAPD analysis for this study because it is a simple and rapid method for determining genetic diversity in various organisms with the advantage that no prior knowledge of the genome under study is needed or the polymorphic function as genetic markers. DNA markers offer accurate identification (William et al., 1990; Weising et al., 1995). This information is valuable for varietial (strain) classification and cross-breeding between different species for potential improvement in commercial production (Purdom, 1993).

\section{MATERIALS AND METHODS}

External morphology study: Barbodes sp. samples were obtained from a Surin province fish farm in northeastern Thailand. Twenty specimens of unknown species were studied using external morphological characteristics as described by Rainboth (1996).

Samples and DNA extraction: Thirty authenticated specimen samples from 3 species, Barbodes gonionatus, B. altus and Barbodes sp., were collected from a Surin province fish farm. The musculature portion was excised and frozen immediately in liquid nitrogen. It was then kept at $-80^{\circ} \mathrm{C}$ until DNA extraction. Total cellular DNA extraction was isolated from each sample using a phenol-chloroform-proteinase $\mathrm{K}$ method (Winnepenninckx et al., 1993). DNA concentrations were determined spectrophotometrically (Maniatis et al., 1982) and extracted DNA were stored at $4^{\circ} \mathrm{C}$ until required.

RAPD-PCR analysis: Twelve decanucleotide primers were screened for amplification success in 3 representative individuals of each species. UBC122 (5'GTAGACGAGC3') and OPA07 (5'GGTGACGCAG3') primers were selected for RAPD analysis. Amplification was carried out in a $25 \mu \mathrm{L}$ reaction volume containing $10 \mathrm{~mm}$ Tris- $\mathrm{HCl}, \mathrm{pH} 8.8$, $50 \mathrm{~mm} \mathrm{KCl}, 1 \%$ Triton-X 100, $2 \mathrm{~mm} \mathrm{MgCl} 2,100 \mathrm{~mm}$ each of dNTP, $0.4 \mu \mathrm{m}$ of a primer, 1 unit of DyNAzyme TM II DNA Polymerase (Finnzymes) and $25 \mathrm{ng}$ of DNA template. PCR was performed in a thermal cycler (Franklin, USA) for 40 cycles including denaturation at $94^{\circ} \mathrm{C}$ for $10 \mathrm{sec}$, annealing at $36^{\circ} \mathrm{C}$ for $30 \mathrm{sec}$ and extension at $72^{\circ} \mathrm{C}$ for $90 \mathrm{sec}$. The final extension was performed at $72^{\circ} \mathrm{C}$ for $5 \mathrm{~min}$. After amplification, PCR products were electrophoretically analyzed through $1.5 \%$ agarose gels, in 0.5XTBE buffer $(50 \mathrm{~mm}$ Tris, $50 \mathrm{~mm}$ Boric Acid, $2.5 \mathrm{~mm}$ EDTA, pH 8.3). Gels were stained with ethidium bromide and photographed under UV light. The sizes of the amplified products were determined by comparison with a 100 bp ladder. Bands were scored as a binary variable, (1) for presence and (0) for absence of band. Only distinct well-resolved stable bands were considered for resolving.

Data analysis: Band-sharing analysis (Jaccard's similarity coefficient) was conducted. Cluster analysis and dendrograms based on the single linkage method were generated to estimate relationships among Barbodes species using NTSYSpc (Rohlf, 1992). The dendrogram was constructed based on data obtained from the two primers.

\section{RESULTS}

External morphological studies found that Barbodes sp. had serrated dorsal-fin spine, soft fins (6-7), 8 branched pelvic fin rays and no adipose fin. 
OnLine J. Biol. Sci., 11 (1): 1-6, 2011

Table 1: Sequences of oligonucleotide primers, sizes and number of scorable RAPD bands, and percentage of polymorphic bands resulting from RAPD analysis using primers OPA07 and UBC122

\begin{tabular}{llll}
\hline Primer & Sequence & $\begin{array}{l}\text { Size range (bp) } \\
\text { (No. of scorable bands) }\end{array}$ & $\begin{array}{l}\text { Percentage of polymorphic bands } \\
\text { (No. of polymorphic bands) }\end{array}$ \\
\hline OPA07 & GGTGACGCAG & $300-1300(13)$ & $61.53(8)$ \\
UBC122 & GTAGACGAGC & $250-2150(22)$ & $86.36(17)$ \\
Average & & & $77.14(12.5)$ \\
\hline
\end{tabular}

Table 2: Total number of bands and percentage of polymorphic and monomorphic bands of each Barbodes species in this study based on RAPD analysis using primers OPA07 and UBC 122

\begin{tabular}{|c|c|c|c|c|c|c|c|c|c|}
\hline & \multicolumn{3}{|c|}{ B. gonionotus } & \multicolumn{3}{|l|}{ B. altus } & \multicolumn{3}{|c|}{ Barbodes sp. } \\
\hline & OPA07 & UBC122 & Total & OPA07 & UBC122 & Total & OPA07 & UBC122 & Total \\
\hline No. of bands & 10 & 16 & 24 & 8 & 8 & 16 & 10 & 16 & 26 \\
\hline No. of polymorphic bands & 0 & 1 & $1(3.9 \%)$ & 0 & 1 & $1(6.3 \%)$ & 0 & 2 & $2(7.7 \%)$ \\
\hline No. of monomorphic bands & 10 & 15 & $25(96.2 \%)$ & 8 & 7 & $15(93.8 \%)$ & 10 & 14 & $24(92.4 \%)$ \\
\hline
\end{tabular}

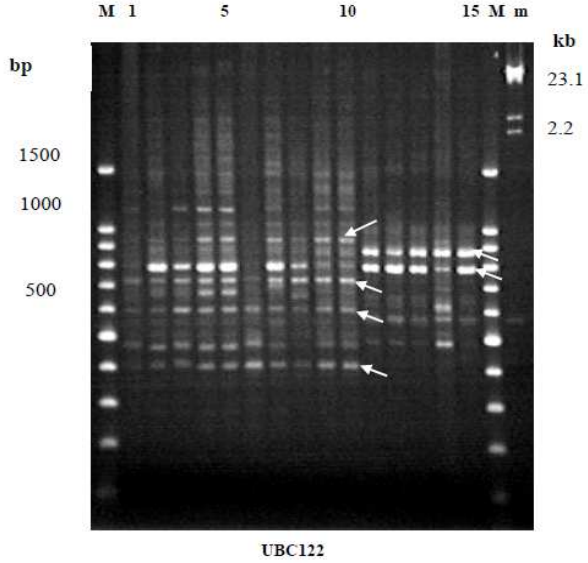

Fig. 1: RAPD pattern of Barbodes sp. (lanes1-5) and $B$. gonionotus (lanes 6-10) and B. altus (lanes1115) generated from RAPD-PCR using primer UBC122, a 100-bp ladder (lane $\mathrm{m}$ ) and $\lambda$ /Hind III (lane $\mathrm{m}$ ) were used as DNA markers. Arrowheads indicate species-diagnosetic RAPD bands described in Table 3

The anal fin had a gold color. The skin of the lower lip was separated from the lower jaw by a shallow groove. The anal fin base length was $90 \%$ of head length. Other characteristics noted were a flat body shape, small head, sharp premaxilla, 2 barbels and no tubercles on the snout. The origin of the dorsal fins was opposite the tenth scale of the lateral line which had 29-31 scales. The body from head to tail was yellow without any red color so the fish was classified as Barbodes species. Characteristics such as the shape and fin of Barbodes sp. are similar to B. gonionatus, but Barbodes sp. has a golden color whereas B. gonionatus is white. The color of Barbodes sp. is similar to $B$. altus, but has no red band on the distal fin. For the result of RAPD analysis, a total of 35 scorable bands ranging from 250-2150 bp was observed

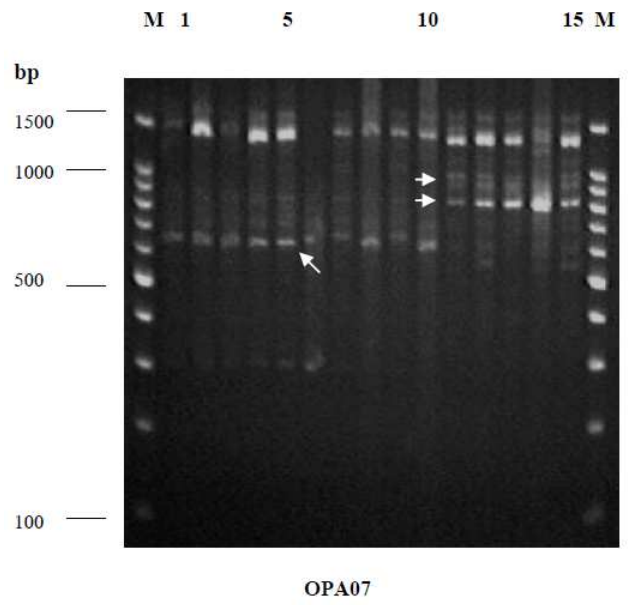

Fig. 2:RAPD pattern of Barbodes sp. (lanes1-5) and $B$. gonionotus (lanes 6-10) and B. altus (lanes1115) generated from RAPD-PCR using primer OPA07, a 100-bp ladder (lane $\mathrm{m}$ ) was used as DNA markers. Arrowheads indicate speciesdiagnosetic RAPD bands described in Table 3

from analysis of three species; Barbodes altus, B. gonionotus and Barbodes sp. using RAPD analysis of two oligonucleotide primers (OPA07 and UBC122) (Fig. 1, 2 and Table 1). The number of amplified bands of all investigated samples were 13 bands for primers OPA07 and 22 bands for UBC122. The percentage of polymorphic bands for each primer was moderate (61.53-86.36\%).

The average number of bands per primer were 12 for B. gonionotus, 8 for Barbodes altus and 13 for Barbodes sp. The percentage of polymorphic bands of the respective species were 3.9, 6.3 and 7.7\% (Table 2) indicating low genetic diversity in each species. The percentage of monomorphic bands were $96.15,93.75$ and $92.39 \%$, respectively. 


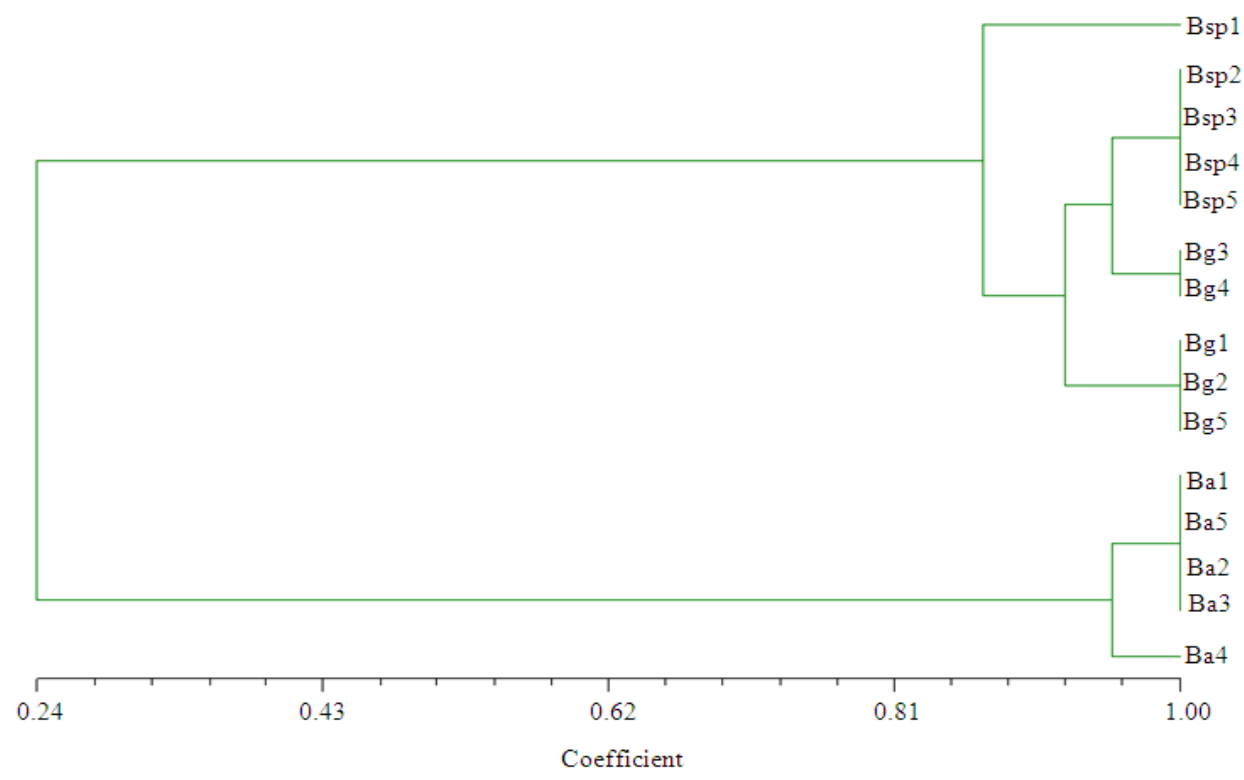

Fig. 3: A hierarchical cluster analysis dendrogram of Barbodes sp. (Bsp), B. gonionotus (Bg) and B. altus (Ba) based on variation of RAPD pattern obtained with OPA07 and UBC122 primer

Table 3: Candidate species-specific RAPD markers of Barbodes sp. in northeastern Thailand revealed by RAPD analysis

\begin{tabular}{|c|c|c|c|}
\hline Primer & $\begin{array}{l}\text { RAPD } \\
\text { marker }\end{array}$ & Species/genus & $\begin{array}{l}\text { Specificity in targe } \\
\text { species }(\%)\end{array}$ \\
\hline OPA07 & 820 and 950 & B. altus & 100 \\
\hline UBC122 & $\begin{array}{l}420,600,720 \\
\text { and } 950\end{array}$ & $\begin{array}{l}\text { B. gonionotus } \\
\text { and Barbodes sp. }\end{array}$ & 100 \\
\hline
\end{tabular}

Candidate species-specific RAPD markers: Several RAPD fragments showed fixed frequencies in each of the particular species. These could be used as speciesspecific markers to distinguish Barbodes species in northeastern, Thailand. The 580 and $890 \mathrm{bp}$ bands generated from UBC122 were fixed in B. altus, but 420 , 600,720 and $950 \mathrm{bp}$ bands were found in $B$. gonionotus and Barbodes sp. Both 820 and 950 bp bands were found only in B. altus and $670 \mathrm{bp}$ in B. gonionotus and Barbodes sp. from OPA07. Thus a distinction between B. altus and B. gonionotus and Barbodes sp. could be recognized by the existence of the $580 \mathrm{bp}$ band from UBC122 in B. altus but which was absent in Barbodes sp. (Fig. 1, 2 and Table 3).

Cluster analysis of the genetic distance values (Jaccard's coefficient) from UBC122 was conducted to generate a dendrogram indicating relationships between the Barbodes species. The genetic distance was $97 \%$ between Barbodes sp. and B. gonionotus and 24\% between B. altus, Barbodes sp. and B. gonionotus. OPA07 was $100 \%$ between Barbodes sp. and $B$. gonionotus and $38 \%$ between B. altus and Barbodes sp. and B. gonionotus, (Fig. 3) which indicates that the relationships between Barbodes sp. and B. gonionotus is closer than B. altus.

\section{DISCUSSION}

External morphological studies found that Barbodes sp. have characteristics described in Rainboth (1996) such as serrated dorsal-fin spines, soft fins (6-7) and 8 branched pelvic fin rays. Anal fins are gold. The skin of the lower lip is seperated from the lower jaw by a shallow groove. Anal fin base length is $90 \%$ of head length, there are no tubercles on the snout and it has a flat body shape, small head, sharp premaxilla and 2 barbels. The origin of the dorsal fin is opposite the tenth scale of the lateral line which has 29-31 scales. The body from head to tail is yellow and there is no red coloration on the body or fins. Therefore the new individual is classified as Barbodes sp. The characteristics of Barbodes sp. are similar to those of B. gonionatus and B. altus, although it has no red coloration on the body or fins.

Two of twelve screened decanucleotides were selected for genetic analysis of Barbodes genera. The results show the RAPD pattern of B. gonionotus and Barbodes sp. as identical main bands after performing with OPA07 and UBC122 primers. RAPD fragments using primer UBC122 found 400, 460, 600, 700, 800 and $920 \mathrm{bp}$, whereas Barbodes altus did not show 400 bp. When using primer OPA07 RAPD fragments show 650 and 1400 bp main bands in 
B. gonionotus and Barbodes sp. but which are absent in $B$. altus. These results are supported by the external morphological results of Barbodes sp. which differed from B. altus and B. gonionotus. Barbodes is more similar in external morphology to $B$. gonionotus than $B$. altus. Thirty-five reproducible and polymorphic fragments (250-2150 bp in length) were generated across the investigated species. The percentages of polymorphic band were $7.69,3.85$ and $6.25 \%$ for Barbodes altus, B. gonionotus and Barbodes sp., respectively. However, the polymorphic values that were performed with both primers were lower than mud crabs in eastern Thailand. Genetic diversity among samples from interspecies was higher than those from intraspecies. The UPGMA indicated that relationships between Barbodes gonionotus and Barbodes sp. were closer than B. altus. Moreover, a candidate species-specific marker of UBC122 primer was found in only Barbodes sp.

Identification of Barbodes species and evaluation of heritability for the growth rate of each Barbodes species are necessary steps for broodstock selection and selective breeding programs in these tax. Our results illustrate that RAPD analysis is a rapid and convenient technique to generate useful genetic markers in Barbodes. Species-diagnostic RAPD markers should be developed which can be utilized to determine from generation to generation a comparison of growth performance of each Barbodes species under commercial growing conditions.

\section{CONCLUSION}

From the above considerations a clear differentiation of the Barbodes sp. from B. gonionotus was achieved. In conclusion, this is the first report showing genetic diversity of Barbodes sp in Thailand. However, an RAPD approach also requires a good quality DNA template for reliable and consistent results which may not be possible for field specimens. Significantly, this may cause false negative results from investigated samples which actually are Barbodes fishes. To eliminate this problem, candidate RAPD fragments should be converted to Sequencecharacterized Amplified Region (SCAR) markers for the next time.

\section{ACKNOWLEDGEMENT}

This research was supported by grants from the Department of Biotechnology, Faculty of Agro-Industrial Technology, Rajamangala University of Technology Isan, Kalasin Campus, Kalasin and Faculty of Science,
Mahasarakam University, Mahasarakam, Thailand. The authors would like to thank Ms. Narumon Prakongruk and Ms. Bupachat Kuntiwong for collecting specimens and preparing chemical reactions in this study.

\section{REFERENCES}

Bond, C.E., 1996. Biology of Fishes. 2nd Edn., Saunders College Publishing, Fort Worth, ISBN10: 0030703425, pp: 768.

Carvalho, G.R. and L. Hauser, 1994. Molecular genetics and the stock concept in fisheries. Rev. Fish. Biol. Fish., 4: 326-350. DOI: 10.1007/BF00042908

Desvignes, J.F., J. Laroche, J.D. Durand and Y. Bouvet, 2001. Genetic variability in reared stocks of common carp (Cyprinus carpio L.) based on allozymes and microsatellites. Aquaculture, 194: 291-301. DOI: 10.1016/S00448486(00)00534-2

Fuchs, H., P. Schlee, J. Blusch, T. Werner and H. Stein et al., 2000. Phylogenetic studies in cyprinid species from central Europe by cytochrome b sequences of mitochondrial DNA. J. Applied Ichthyol., 16: 79-82. DOI: 10.1046/j.14390426.2000 .00162

Holmen, J., L.A. Vollestad, K.S. Jakobsen, and C.R. Primmer, 2005. Cross-species amplification of zebrafish and central stoneroller microsatellite loci in six other cyprinids. J. Fish Biol., 66: 851-859. DOI: 10.1111/j.0022-1112.2005.00637

Larno, V., S. Launey, A. Devaux, and J. Laroche, 2005. Isolation and characterization of microsatellite loci from chub Leuciscus cephalus (pisces: Cyprinidae). Mol. Ecol. Notes, 54: 752-754. DOI: 10.1111/j.1471-8286.2005.01052

Maniatis, T., E.F. Fritsch and J. Sambrook, 1982. Molecular Cloning: A Laboratory Manual. Cold Spring Harbor, Cold Spring Harbor Laboratory Press, New York, ISBN: 0879691360, pp: 545.

Purdom, C.E., 1993. Genetic and fish breeding. Ministry of Agriculture. Fisheries and Food. pp: 376. ISSN: 14154757

Rainboth, W.J., 1996. Fishes of the Cambodian Mekong. FAO Species Identification Field Guide for Fishery Purpose. Mekong River Comission, FAO and DANIDA, ISBN: 9251037434, pp: 265.

Rohlf, F.J., 1992. NTSYS-PC: Numerical Taxonomy and Multivariate Analysis System. Exeter Software, New York, pp: 236. ISSN: 15362442 
Shimoda, N., E.W. Knapik, J. Ziniti, C. Sim and E. Yamada et al., 1999. Zebrafish genetic map with 2000 microsatellite markers. Genomics, 58: 219232. DOI:10.1006/geno.1999.5824

Weising, K., H. Nybom, K. Wolf and W. Meyer. 1995. DNA Fingerprinting in Plant and Fungi. Boca Raton, CRC Press, Fla, London, pp: 472. ISSN: 10958290

William, J.G.K., A.R. Kubelik, K.L. Livak, J.A. Rafalski and S.V. Tingey, 1990. DNA polymorphisms amplified by arbitrary primers are useful as genetic markers. Nucleic Acids Res., 18: 6531-6535. DOI: 10.1093/nar/18.22.6531

Winnepenninckx, B., T. Backeljau and R. De Wachter. 1993. Extraction of high molecular weight DNA from mollusk. Trends Genetics, 9: 407. DOI: 10.1016/0168-9525(93)90102-N
Zhou, J.F., Q.J. Wu, Y.Z. Ye and J.G. Tong, 2003. Genetic divergence between Cyprinus carpio carpio and Cyprinus carpio haematopterus as assessed by mitochondrial DNA analysis, with emphasis on origin of European domestic carp. Genetica, 119: 93-97. DOI: 10.1023/A:1024421001015

Zhou, L., Y. Wang and J.F. Gui, 2001. Molecular analysis of silver crucian carp (Carassius auratus gibelio Bloch) clones by SCAR markers. Aquaculture, 201: 219-228. DOI: $10.1016 / \mathrm{S} 00448486(01) 00603-2$ 